without the use of probenecid may, however, fail to produce adequate levels at skin surfaces and in the bronchial tree. We have also seen an anuric patient in whom Pseudomonas persisted in the bladder despite a blood carbenicillin level of $750 \mu \mathrm{g} . / \mathrm{ml}$.

Perhaps the most fruitful approach to this problem would be the application of suitable topical agents, but not carbenicillin, to any potentially infected accessible sites. Such treatment reduces dissemination from colonized sites and, used in conjunction with systemic treatment, might reduce the emergence and spread of carbenicillin-resistant strains. Though we have been unable to show convincing synergy between carbenicillin and gentamicin, their combined use might be justified to prevent the selection of resistant mutants.
We wish to thank our clinical colleagues under whom the patients referred to were admitted, Miss Audrey Fryer-Kelsey for her technical assistance, and Mrs. Beryl Devenyi for pyocine-typing the strains.

\section{REFERENCES}

Brumfitt, W., Percival, A., and Leigh, D. A. (1967), Lancet, 1, 1289. Garrod, L. P. (1951). British Medical fournal, 1, 205

Gillies, R. R., and Govan, J. R. W. (1966). Fournal of Pathology and Bacteriology, 91, 339 .

Richardson, A. E., Spittle, C. R., James, K. W., and Robinson, O. P. WO (1968). Postgraduate Medical fournal, 44, 844

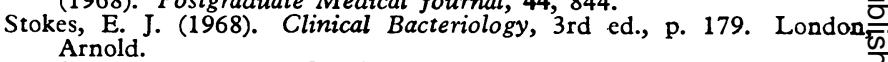

Stratford, B. C. (1968). Medical fournal of Australia, 2, 890.

Van Rooyen, C. E., Ross, J. F., Bethune, G. W., and MacDonald, A. C (1967). Canadian Medical Association fournal, 97, 1227.

\title{
Effects of $\beta$-Adrenergic Receptor Blockade on Airway Conductance and Lung Volume in Normal and Asthmatic Subjects
}

\author{
P. S. RICHARDSON,* B.M., B.SC.; G. M. STERLING, † M.B., M.R.C.P.
}

Summary : Ten normal and five asthmatic subjects were given intravenous injections of $10 \mathrm{ml}$. of $0.9 \%$ saline with and without $10 \mathrm{mg}$. of propranolol, and specific airway conductance was followed in a whole-body plethysmograph. Saline alone had no significant effect on conductance in either group of subjects. Propranolol had no significant effect on conductance in normal subjects, but caused a mean fall of $\mathbf{3 4 . 9 \%}$ in the asthmatics.

\section{Introduction}

Blockade of $\beta$-adrenergic receptors by propranolol in asthmatic subjects often causes wheezing and a pronounced decrease in vital capacity (V.C.) and forced expiratory volume in one second (F.E.V..$_{1}$ ) (McNeill, 1964 ; Langer, 1967). The effect of $\beta$-blockade on the airways of normal subjects is less certain : Zaid and Beall (1966) found no change in F.E.V.1 after propranolol, and Marcelle et al. (1968) obtained the same result, using the interrupter method to measure airway resistance. On the other hand, McNeill and Ingram (1966) and MacDonald et al. (1967), who used the more sensitive method of whole-body plethysmography, reported a significant increase in airway resistance in normal as well as asthmatic subjects after intravenous propranolol. This question is examined further in the present paper, in which the effects of propranolol on airway calibre of normal and asthmatic subjects are compared.

\section{Subjects and Methods}

Ten normal adults with no history or signs of chest disease and five asthmatic subjects were studied. The latter were all clinical students or junior medical staff who agreed to take part in the trial after being informed of the possible effects of propranolol on airway resistance in asthmatics. At the time of testing they were all symptom-free, had had no major attack of asthma for at least three months, and had a resting F.E.V..$_{1}$ of more than 2 litres.
Airway resistance (Raw) and thoracic gas volume (Vtg) were measured by means of a constant-volume whole-body plethysmograph (DuBois et al., 1956a, 1956b). During the measurements the subjects performed shallow panting at? about two breaths per second through a Fleisch pneumotacho- $\frac{D}{D}$ graph head, and flow and pressure signals were displayed as vector loops, the slopes of which were measured by visualo alignment with a rotating Perspex disc mounted in front of the oscilloscope screen (Sterling, 1968). Each value of Raw was derived from the average of five successive short periods of panting after the first two had been discarded. Vtg was measured by the method of DuBois et al. (1956a) during? attempted gentle respiratory efforts made against a shutter occluding the airway at the mouth. After subtraction of $0.45 \mathrm{~cm} . \mathrm{H}_{2} \mathrm{O} / 1 . / \mathrm{sec}$. for the resistance of the pneumotachograph head and mouth-piece, Raw was converted to its reciprocal, airway conductance (Gaw), and results are ex-은 pressed as changes in the ratio:

$$
\frac{\mathrm{Gaw}}{\mathrm{Vtg}}=\text { Specific airway conductance (SGaw). }
$$

Experiments on each subject were done on two days, on $\widetilde{N}$ one of which $10 \mathrm{mg}$. of propranolol in $10 \mathrm{ml}$. of $0.9 \%$ saline $\omega$ was injected intravenously, and on the other $10 \mathrm{ml}$. of saline alone. The order of the injections was varied, 7 out of 100 normal subjects and three out of five asthmatics receiving $\Phi$ propranolol first. Raw and Vtg were measured at 15-minute?+intervals before and after the injections in order to assess $\frac{0}{0}$ spontaneous variability and not to miss any delayed responses. The tests were done "blind" in that the operator reading $\frac{\rho}{\mathbb{0}}$ the vector slopes was not informed of the contents or order $\varrho$ of the injections until the end of the study. The subjects were unable to distinguish between saline and propranolol, and 8 were unaware of the order of injections.

* House-physician, Respiratory Department, St. George's Hospital, London S.W.1.

† Research Registrar, Respiratory Department, St. George's Hospital, London S.W.1. Present address: University Laboratory of Physiology, Oxford.

Reprint requests to: Dr. P. S. Richardson, St. George's Hospital, London 


\section{Raw, Vtg, SGaw}

Results

Individual changes in SGaw after saline and propranolol are shown in Fig. 1. Each point represents the average of three values at 15-minute intervals either before or after the injection. There was a consistent fall in SGaw only after propranolol in asthmatics, but 3 of the 10 normals also showed small falls. Saline alone had no apparent effect on SGaw in either normal or asthmatic subjects.

Mean values of SGaw ( +1 S.D.) before and after treatment are given in the Table. Changes were tested for significance with a standard $t$ test, so that each subject served as his own control, and the results confirm the impression gained from Fig. 1 that the only significant change occurred when propranolol was given to asthmatic subjects. In making this calculation the mean value before or after treatment again consisted of the average of the three values at 15-minute intervals. This method of comparison has the advantage of increasing the reliability of the control value of SGaw but the disadvantage of tending to swamp any transient effect of saline or propranolol. Mean values for each time of measurement were therefore also calculated, and are shown in Figs. 2 and 3. There was a clear fall in mean SGaw after propranolol in asthmatic subjects at the first measurement after the injection (8-12 minutes), and this was maintained for at least a further 30 minutes. In the normal subjects there was a small transient fall in mean SGaw at the first measurement after the injection, but comparison of this value with either the grand mean before or the single mean value immediately before the injection showed that there was no significant change $(t=0.93, \mathrm{P}>0.3 ; t=1.85, \mathrm{P}>0.05$, respectively).

Changes in Raw, Vtg, and SGaw After Saline and Propranolol

\begin{tabular}{|c|c|c|c|c|c|}
\hline & & \multicolumn{2}{|c|}{$\operatorname{Normal}(n=10)$} & \multicolumn{2}{|c|}{ Asthmatic $(n=5)$} \\
\hline & & Saline & Propranolol & Saline & Propranolol \\
\hline $\begin{array}{l}\text { Raw } \\
\pm 1 \text { S.D. } \\
(\mathrm{cm} . \\
\left.\mathrm{H}_{2} \mathrm{O} / 1 . / \mathrm{sec} .\right)\end{array}$ & $\begin{array}{l}\text { Before } \\
\text { After } \\
\text { Change } \\
\text { Sig. }\end{array}$ & $\begin{array}{c}1.56 \pm 0.44 \\
1.52 \pm 0.38 \\
-1.6 \% \\
P>0.3\end{array}$ & $\begin{array}{c}1.41 \pm 0.46 \\
1.44 \pm 0.45 \\
+3.5 \% \\
P>0.3\end{array}$ & $\begin{array}{c}1.81 \pm 0.50 \\
1.79 \pm 0.35 \\
+0.6 \% \\
P>0.4\end{array}$ & $\begin{array}{c}1.90 \pm 0.66 \\
2.79 \pm 0.96 \\
+48.9 \% \\
P<0.02\end{array}$ \\
\hline$\underset{\text { (litres) }}{\text { Vtg } \pm 1 \text { S.D. }}$ & $\begin{array}{l}\text { Before } \\
\text { After } \\
\text { Change } \\
\text { Sig. }\end{array}$ & $\begin{array}{c}3.76 \pm 0.84 \\
3.72 \pm 0.82 \\
-0.9 \% \\
P>0.4\end{array}$ & $\begin{array}{c}4 \cdot 14 \pm 1 \cdot 24 \\
4.05 \pm 1 \cdot 14 \\
-1 \cdot 8 \% \\
P>0.3\end{array}$ & $\begin{array}{l}4.86 \pm 1.08 \\
5 \cdot 20 \pm 1.05 \\
+8 \cdot 1 \% \\
P>0.1\end{array}$ & $\begin{array}{c}4.54 \pm 1 \cdot 00 \\
4.89 \pm 1 \cdot 31 \\
+7.3 \% \\
P>0.1\end{array}$ \\
\hline $\begin{array}{c}\text { SGaw } \\
\pm 1 \text { S.D. }\end{array}$ & $\begin{array}{l}\text { Before } \\
\text { After } \\
\text { Change } \\
\text { Sig. }\end{array}$ & $\begin{array}{c}0.188 \pm 0.05 \\
0.193 \pm 0.05 \\
+3.0 \% \\
\mathbf{P}>0.1\end{array}$ & $\begin{array}{c}0.199 \pm 0.06 \\
0.195 \pm 0.05 \\
-0.9 \% \\
P>0.7\end{array}$ & $\begin{array}{c}0.120 \pm 0.02 \\
0.114 \pm 0.02 \\
-6.0 \% \\
P>0.1\end{array}$ & $\begin{array}{c}0.130 \pm 0.04 \\
0.085 \pm 0.04 \\
-34.9 \% \\
P<0.005\end{array}$ \\
\hline
\end{tabular}

Change $=$ Mean of individual percentage changes
The expression SGaw is commonly used as an index of "active" airway obstruction, since it allows a correction to be made for the passive mechanical effects of lung inflation on airway calibre and hence on resistance and conductance (Guyatt et al., 1967). It is, however, only an approximate correction, and the mean values of Raw and Vtg are therefore also given in the Table. The fall in SGaw which occurred after propranolol in asthmatic subjects can be seen to be due to a rise in uncorrected Raw, since there was no significant change in Vtg.

\section{Discussion}

Bronchial smooth muscle is supplied by parasympathetic (vagal) and sympathetic efferent fibres, of which the former cause constriction and the latter dilatation when stimulated $\bar{c}$ in various animal species (Widdicombe, 1966). There is good evidence for some vagal bronchoconstrictor activity at rest $\exists$ in man, since atropine causes bronchodilatation in normal subjects (Severinghaus and Stupfel, 1956 ; Nadel and Comroe, of 1961 ; Sterling, 1967), but the role of the sympathetic nervous system and circulating catecholamines in regulating bronchial $\vec{\overrightarrow{ }}$ calibre at rest is less certain. It has recently been suggested $\vec{\omega}$ that there is some $\beta$-adrenergic bronchodilator "tone" 의 normally present in animals and man (McNeill and Ingram, $\vec{\omega}$ 1966 ; McCulloch et al., 1967 ; MacDonald et al., 1967).

The absence of a significant fall in SGaw after intravenous propranolol $10 \mathrm{mg}$. indicates the absence of any detectable $\vec{\varphi}$ resting $\beta$-adrenergic bronchodilator activity in the present 8 normal subjects. Control experiments with an injection of the same volume of saline showed that the procedure itself 0 had no effect on SGaw, and observer bias was excluded so far as was possible, since the person measuring the slopes of the vector loops did not know which solution had been $\frac{0}{D}$ injected. The fact that the subjects themselves did not know $\varrho$ whether they had been given saline or propranolol may be $\overrightarrow{\overrightarrow{0}}$ important, since it has recently been reported that, at least in 3 asthmatic subjects, the response of the airways to inhalation of an inactive aerosol may be influenced by the expectation of either a bronchoconstrictor or bronchodilator effect (Lyons et al., 1968). This was supported by the response of one asthmatic subject in the present group; having already, in $\frac{5}{3}$ fact, received propranolol but without developing symptoms, he believed that the second injection would be the active one, $\delta$ and his SGaw duly fell after saline.

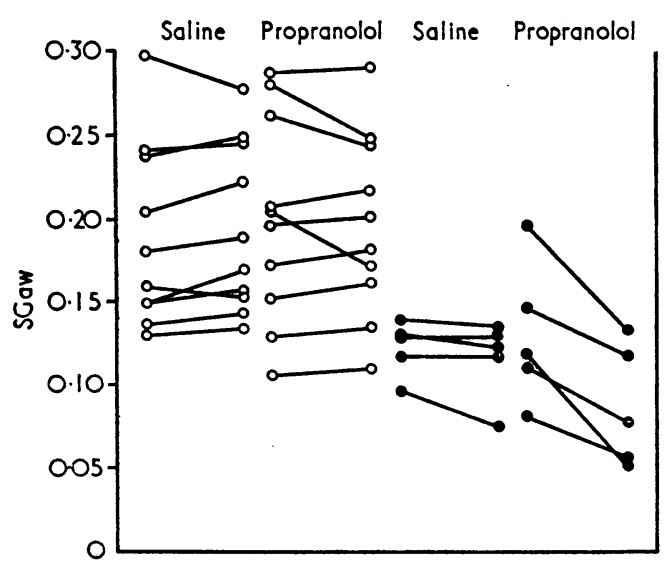

FIG. 1

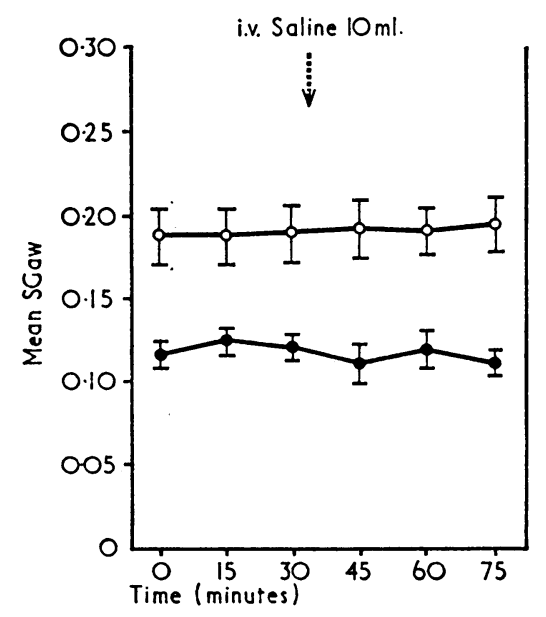

FIG. 2

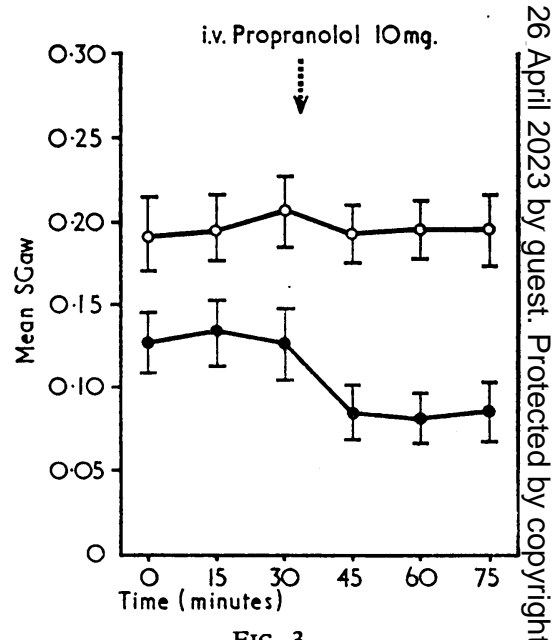

FIG. 3

Fig. 1.- Individual values of $S G a w$ before and after intravenous saline and intravenous propranolol $10 \mathrm{mg}$. $O-O$ normal subjects. -2 asthmatics. FIG. 2.- Mean values of $S G a w+1$ S.E.M. for 10 normal and five asthmatic subjects at intervals before and after intravenous saline. before and after intravenous propranolol. O-O vormal subjects. 0 normal subjects. for 10 normal and five 
The explanation of the difference between the present results and those of MacDonald et al. (1967) is uncertain. The mean rise of $93 \%$ in airway resistance which they reported may have been due partly to a decrease in lung volume, since they do not quote values for the latter, but this is unlikely to have been enough to account for the whole response, particularly since propranolol did not significantly alter Vtg in the present experiments (see Table).

Another possible factor is the timing of measurements, since MacDonald et al. (1967) compared control values of airway resistance with peak response values, which sometimes occurred as soon as two minutes after the injection and always within 20 minutes. Our first set of measurements were made 8 to 12 minutes after injection and are therefore unlikely to have missed many peak responses, but even when only this set of measurements was compared with the control values there was no significant change in SGaw.

Although the above two factors may have played a small part, the most probable explanation of the difference in results is that of subject selection. There is wide variation in individual response to propranolol, five out of 18 subjects reported by MacDonald et al. (1967) showing increases of airway resistance of less than $15 \%$ and two of $300 \%$ or more. Three of our 10 normal subjeots showed a distinct fall in SGaw after propranolol, though the change in the group as a whole was not significant. The absence of clinically important $\beta$-adrenergic bronchodilator activity in non-asthmatic subjects is confirmed by the rarity of respiratory symptoms in hypertensive patients treated with large doses of propranolol (Prichard and Gillam, 1969).

The decrease in SGaw seen in the present asthmatic subjects confirms previous findings of a bronchoconstrictor response to propranolol (McNeill, 1964; Zaid and Beall,
1966 ; Langer, 1967 ; MacDonald et al., 1967). Even mild asthmatics thus appear to have increased $\beta$-adrenergic bronchodilator activity at rest, which persists despite the absence of symptomatic airway obstruction.

We should like to thank Dr. J. C. Batten for his advice and encouragement, and Miss F. A. Boother and Mrs. J. Unwin fợ their technical help. One of us (G. M. S.) was supported by research grant from the Board of Governors, St. George's Hospitas, London.

\section{REFERENCES}

DuBois, A., Botelho, S. Y., Bedell, G. N., Marshall, R., and Comro@ J. H., jun. (1956a). Fournal of Clinical Investigation, 35, 322. DuBois, A. B., Botelho, S. Y., and Comroe, J. H., jun. (1956b). foumin of Clinical Investigation, 35, 327.

Guyatt, A. R., Alpers, J. H., Hill, i. D., and Bramley, A. C. (19672 fournal of Applied Physiology, 22, 383 .

Langer, I. (1967). Fournal of Physiology, 190, 41P. Proceedings of $24 \mathrm{th}$ International Congress of Physiological Sciences $7,273$.

McCulloch, M. W., Proctor, C., and Rand, M. J. (1967). Europeakn

Fournal of Pharmacology, 2, 214.
MacDonald, A. G., Ingram, C. G., and McNeill, R. S. (1967). Britis fournal of Anaesthesia, 39, 919.

McNeill, R. S. (1964). Lancet, 2, 1101.

McNeill, R. S., and Ingram, C. G. (1966). American fournal of Cardio

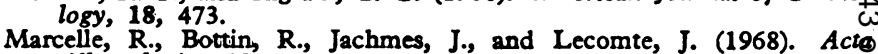
Allergologica, 23, 11 .

Nadel, J. A., and Comroe, J. H., jun. (1961). fournal of Applied Physio logy, 16, 713.

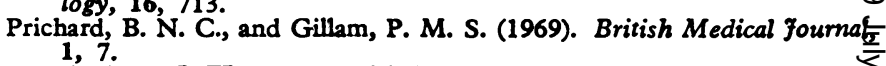

Severinghaus, J. W., and Stupfel, M. (1956). Fournal of Applied Physio= $\log y, 8,81$.

Sterling, G. M. (1967). British Medical fournal, 3, 275.

Sterling, G. M. (1968). Clinical Science, 34, 277

Widdicombe, $\mathrm{J}$ edited by

Zaid, G., and Beall, G. N. (1966). New England fournal of Medicino 275,580 .

\title{
Dietary Sugar and Ischaemic Heart Disease
}

\author{
R. W. HOWELL,* F.M.R.: ; D. G. WILSON, $\dagger$ M.B., D.I.H., D.oBST.R.C.o.G.
}

Summary : Comparison of the sugar intake of 1,158 men 1 believed to be free of ischaemic heart disease failed to establish any real difference in intake when compared with 170 men with confirmed or possible ischaemic heart disease. In neither group was there any significant correlation between sugar intake and serum cholesterol, white blood cell count, haemoglobin, E.S.R., $\beta$-lipoprotein, or uric acid; nor was there any correlation between total sugar intake and weight gain after the age of 25 years.

These results suggest that considerably more confirmation is required before acceptance of Yudkin's hypothesis that high sugar intake is the chief dietary factor causing ischaemic heart disease.

\section{Introduction}

Considerable interest has been aroused by the proposition (Yudkin, 1957) that high sugar intake is the chief dietary factor causing ischaemic heart disease (I.H.D.). This suggestion has not been sustained in man in any large inquiry; indeed,
Paul, MacMillan, McKean, and Park (1968) found " nothing like the twofold difference in sucrose intake between coronaryo and non-coronary groups desoribed by Yudkin and Roddy."W Results from other countries, however, are not always repro ducible in Britain, and further reports are essential. In thise survey an attempt has been made to relate sugar intake to ischaemic heart disease from a prospective five-year heart study. now being carried out at four U.K. Atomic Energy Authority establishments.

\section{Patients and Methods}

The survey population of 2,700 was a random male sample born in the years 1912 to 1926 inclusive. Over $90 \%$ of those originally selected have entered the survey (though those not free from I.H.D. at entry will have to be omitted from most

\footnotetext{
* Authority Health and Safety Branch, Harwell, United Kingdom Atomic Energy Authority.

t Medical Officer, Dounreay Experimental Reactor Establiahment,
United Kingdom Atomic Energy Authority.
} 